\title{
RUPTURE OF INTRAMEDULARY SPINAL CORD CAVERNOUS HEMANGIOMA
}

\author{
I Fadhilah S1, Meiti Frida², Basjiruddin Ahmad ${ }^{3}$
}

\begin{abstract}
Abstrak
Intramedulary spinal cord cavernous hemangioma merupakan malformasi vaskular yang jarang terjadi. Angka kejadian cavernous hemangioma pada spinal cord berkisar 5\%-12\% dari keseluruhan vaskular anomali pada spinalis. Gejala klinis timbul akibat adanya kompresi pada spinal cord yang bersifat slowly progresive. Malformasi ini memiliki resiko yang tinggi untuk pecah dikarenakan tipisnya dinding pembuluh darah yang membentuknya.

Seorang pasien laki-laki usia 51 tahun dirawat dengan kelemahan keempat anggota gerak yang progresif asimetris sejak 4 bulan sebelum masuk rumah sakit. Keluhan diawali dengan kebas dan berkurangnya sensasi raba mulai dari leher kebawah sejak 5 bulan sebelum dirawat. Nyeri pada tengkuk disertai dengan gangguan miksi sejak 2 bulan sebelum dirawat. Dari pemeriksaan neurologis didapatkan tetraparesis dengan gangguan sensorik berbatas tegas setinggi dermatom C3- C4. Pada pemeriksaan MRI medula spinalis segmen cervikal didapatkan gambaran suatu cavernous hemangioma (Cavernoma) pada medulospinalis junction dengan gambaran komponen perdarahan pada kanalis spinalis. Pasien direncanakan untuk tindakan operatif dengan resiko berat dan prognosis yang buruk post operatif. Ruptur Cavernous Hemangioma perlu dipertimbangkan pada pasien tetraparese dengan gejala lesi upper motor neuron, meskipun kasus ini jarang terjadi
\end{abstract}

Kata Kunci : Tetraparese, Ruptur cavernous Hemangioma, cervical spinalcord

\section{Abstract}

Intramedullary spinal cord cavernous hemangioma is a rare vascular malformations. The incidence of vertebral cavernous hemangioma is 3\% -12\% of overall vascular anomalies in the spinal. Clinical symptoms arise due to slowly progressive compression on spinal cord. This malformation has a high risk of rupture due to their thinner walls.

A 51 years old male patient treated with progressive asymetric weakness of his four limbs since 4 months before admission. Its preceded with numbness and reduced touch sensation from the neck down 5 months before admission. Pain in his nape with micturition disorders since 2 months before admission. On neurological examination obtained tetraparese with sensory disorders as high as C3-C4. MRI of the spinal cord cervical segment obtained an image of a cavernous hemangioma (cavernoma) in medulospinalis junction with bleeding in the spinal canal. Spinal cord surgery was suggested with high risk and poor post-operative prognosis.

Ruptured Cavernous hemangioma must be considered in tetraparese with upper motor neuron symptoms, although these cases are rare.

Key words: Tetraparesis, Ruptur cavernous Hemangioma, cervical spinalcord

Affiliasi penulis : 1. RS Jiwa.HB.Saanin Padang 2. Bagian Neurologi FK Unand/ RSUP Dr. M. Djamil, Padang. 3. Bagian Neurologi FK Unand /RSUP Dr.M.Djamil Padang

Korespondensi : I Fadhilah S e-mail : fadhils13diamond@gmail.com Telp/HP :081374169900

\section{PENDAHULUAN}

Intramedulary spinal cord cavernous hemangioma merupakan malformasi vaskular yang jarang terjadi. Angka kejadian cavernous hemangioma pada vertebral berkisar 5\%-12\% dari keseluruhan vaskular anomali pada spinalis dan hanya $5 \%$ terdapat pada intramedular medula spinalis. Cavernous hemangioma (Cavernoma) sering ditemukan pada usia 20-40 tahun dan hanya $1 \%$ terjadi pada anak-anak. (1) Malformasi ini sering timbul tanpa gejala sehingga jarang dipikirkan dan sering ditemukan tanpa sengaja dari pemeriksaan MRI. Pada keadaan dimana cavernous hemangioma memberikan munculan klinis, Gejala klinis yang timbul berupa gejala kompresi pada spinal cord yang dapat bersifat slowly progresive. Malformasi ini juga memiliki resiko yang tinggi untuk ruptur dikarenakan tipisnya dinding pembuluh darah yang membentuk cavernous angioma. Angka kejadian rupturnya cavernoma berkisar antara 0,7 - 1,7 per lesi/ tahun.(2) Penatalaksanaannya membutuhkan tindakan operatif dengan resiko operasi dan pasca operasi yang bervariasi sesuai dengan lokasi lesi dan gejala neurologis yang timbul.

\section{LAPORAN KASUS}

Seorang laki-laki usia 51 tahun dirawat dibagian saraf RSUP M.Djamil dengan keluhan lemah keempat anggota gerak sejak 4 bulan yang lalu yang terjadi berangsur-angsur. Awalnya pasien masih dapat 
berjalan dengan menyeret tungkai kiri sejak 2 bulan ini pasien tidak lagi dapat berjalan sama sekali hanya dapat berbaring ditempat tidur.

Keluhan diawali dengan rasa kebas dan berkurangnya sensasi raba mulai dari setinggi leher kebawah sejak 5 bulan sebelum masuk RS. Keluhan dirasakan semakin hari semakin bertambah berat. Nyeri radikular pada tengkuk yang menjalar hingga ke lengan sejak 2 bulan sebelum masuk RS, hilang timbul dan bersifat kronik progresif . Pasien tidak bisa buang air kecil sejak 2 bulan sebelum masuk RS dan dilakukan pemasangan kateter. Tidak ada riwayat keganasan pada paru, saluran cerna dan prostat. Tidak ada riwayat TB paru sebelumnya.

Dari pemeriksaan nervus cranialis tidak ditemukan defisit nervus cranialis, reflek muntah dan fungsi menelan baik. Didapatkan tetraparese dengan (kekuatan ekstremitas atas 110/223 dan ekatremitas bawah 111/111, hipertonus dan disuse atrofi. Didapatkan peningkatan reflek fisiologis pada keempat ekstremitas serta ditemukan adanya hofman tromner pada kedua ekstremitas atas dan babinski pada kedua ekstremitas bawah. Dari pemeriksaan sensorik didapat gangguan sensasi raba, suhu setinggi dermatom C3C4 kebawah dengan disertai gangguan sensasi getar dan posisi sendi.

Pada pemeriksaan laboratorium didapatkan HB: 10,4 g/dl, Leukosit :7.700/mm3, hematokrit: $32 \%$ dan trombosit 138.000/mm3, albumin:2,1 g/dl, globulin 2,6 g/dl. PT:11,1 dan APTT:32,2. Foto rotgen paru dan foto rotgen vertebra cervical tidak tampak kelainan.

Awalnya didiagnosis sebagai space occupaying lession di medula spinalis suspek tumor primer intramedular setinggi segmen medula spinalis C3-C4 yang mengarah pada suatu ependimoma. Diagnosis banding lain berupa Astrocytoma, Arteriovena Malformasi dan Cavernous Angioma.

Pemeriksaan MRI Cervical didapatkan gambaran; Pada regio medulospinalis junction (pangkal spinalcord) tampak gambaran lesi berdensitas signal hiperintens pada T1W, T2W dan T1RM, serta dikelilingi oleh area yang hipo intens dengan ukuran $1,8 \mathrm{~cm} \times 1,4 \mathrm{~cm}$ dan tampak lesi tersebut ruptur dengan perdarahan ke canalis centralis (Spinal cord) dengan gambaran syringomyelia setinggi C2 sampai C4. Setelah dilakukan pemberian kontras tidak ada perubahan (tidak enhance). Corpus vertebrae baik. Dari gambaran tersebut disimpulkan sebagai Cavernoma pada pangkal spinal cord dengan ruptur perdarahan sub akut ke kanalis centralis (Syringomyelia).
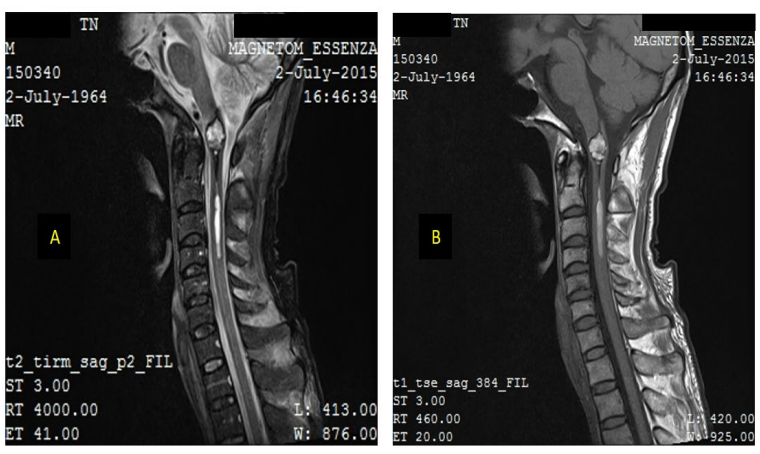

Gambar 1. MRI Sagital (A) T2 TIRM dan (B) T1 TSE, Lesi hiperintens yang dikelilingi area hipointens dengan perdarahan ke canalis centralis dengan syringomyelia setinggi $\mathrm{C} 2$ - C4

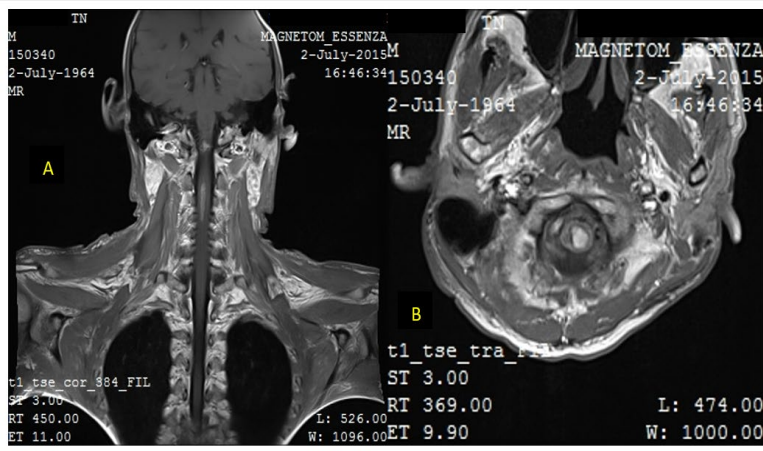

Gambar 2. MRI Coronal (A) T1 TSE (B),

Aksial T1 TSE Cavernous Haemangioma pada cervicomedulari Junction, ukuran 1,8×1,4 cm

Berdasarkan gamabaran MRI dan gejala klinis yang didapatkan, kami mendiagnosis sebagai cavernous angioma pada intramedular segmen C3C4. Namun diagnosis pasti berdasarkan pemeriksaan histopatologi. Selama dalam rawatan pasien mendapat terapi konservatif dengan pemberian kortikosteroid, metylprednisolon 4 × $250 \mathrm{mg}$ intravena (tappering off) dan pemberian terapi simptomatik lainnya. Penatalaksanaan pada kasus ini seharusnya dengan tindakan operatif namun memiliki resiko yang besar karena lokasi pada segmen cervikal atas.

\section{PEMBAHASAN}

Cavernous hemangioma dikenal juga dengan nama cavernoma atau cavernous angioma. Cavernoma merupakan suatu malformasi vaskular pada pembuluh 
darah yang membentuk seperti buah mulberry atau raspberry yang memiliki dinding sinusoids yang tipis, yang dilapisi oleh selapis tipis endotel, dan dikelilingi oleh deposit hemosiderin dan glosis serta tidak memiliki jaringan neuronal di dalamnya. (1)

Cavernoma pada susunan sistem saraf pusat merupakan kondisi yang langka, pada satu tingkat populasi, cavernoma sistem saraf pusat hanya terjadi pada $0.1 \%$ hingga $0.9 \%$ orang. Sementara itu angka kejadian cavernoma pada spinal cord berkisar antara 5-12 \% dari keseluruhan malformasi vaskular abnormal dan $5-23 \%$ nya terjadi pada intramedulary. $(1: 1,5)^{(2)}$. Cavernoma biasa ditemukan secara tidak sengaja terutama saat pemeriksaan MRI. Intramedulary cavernoma sering ditemukan pada dekade ketiga dan keempat dengan perbandingan antara laki-laki dan perempuan yang relatif sama. (3)

Secara makroskopik tampak sebagai lesi berwarna merah keunguan, memiliki variasi ukuran, mulai dari $1 \mathrm{~mm}$ hingga beberapa sentimeter. Malformasi ini dapat multiple ataupun single, seringkali berkapsul dan multilobar. Secara histopatologi, pada sistem saraf pusat terlihat sebagai sarang madu yang irregular dengan rongga-rongga yang terisi oleh darah di dalamnya. (1)(2) Pada mikroskop elektron terlihat dinding cavernoma hanya memiliki sedikit ikatan subendothelial dan jaringan ikat di antara masingmasing sel endotelnya. Sehingga memungkinkan terjadinya perdarahan mikro pada cavernoma sistem saraf pusat, perdarahan mikro tersebut yang memberikan gambaran makrofag dengan hemosiderin di dalamnya. (1)(3)

Rongga vaskular yang terletak di dalam cavernoma dipisahkan oleh matriks kolagen, dan deposit kalsium sering ditemukan pada cavernoma terutama pada dinding vaskularnya. Pada cavernoma, tidak ditemukan adanya jaringan saraf, dan ini merupakan salah satu kriteria diagnosis dan tanda kardinal klasik yang dimiliki oleh cavernoma sistem saraf pusat. (4)

Ada beberapa subtype pada cavernoma sistem saraf yang telah berhasil diidentifikasi, antara laint terdapat tiga tipe yaitu Bentuk kistik, bentuk dural (dural-based form) dan bentuk Hemangioma terklasifikasi. (1)
Penyebab utama dari cavernoma masih belum dapat dijelaskan. Beberapa laporan kasus menyatakan radiasi, malformasi vascular yang koeksis, faktor hormonal, hingga pembentukan cavernoma pada kondisi immunosupresi telah dilaporkan, tetapi penelitian telah menunjukan bahwa keterlibatan herediter atau genetika merupakan salah satu faktor penting dalam pembentukan cavernoma. ${ }^{(5)}$ Pada awal tahun 1980-an, telah ditemukan beberapa bukti bahwa pembentukan cavernoma terjadi dikarenakan faktor genetika. Penelitian tersebut telah berhasil menunjukan keterlibatan genetika pada kasus ini, cavernoma dapat muncul dalam bentuk familial dengan pola keturunan autosomal dominan dan diperkirakan terjadi akibat "two-hit model" seperti yang terjadi pada retinoblastoma. Penelitian laboratorium selanjutnya menunjukan beberapa gen yang memiliki keterlibatan dengan pembentukan cavernoma yaitu CCM1, CCM2 dan CCM3. Ketiga gen ini terlibat bersama-sama dan saling mempengaruhi neuron dan glia terhadap endothelium dari sistem saraf pusat. (3)

Berdasarkan korelasi dengan gambaran histologikal, cavernoma dapat memberikan beberapa gambaran perjalanan klinis yang berbeda. Dapat dikelompukkan menjadi empat macam perjalanan klinis; (1). Episode akut deteriorasi neurologis; (2) Slowly progresive deteriorasi neurologis; (3) Onset akut deteriorasi neurologis dengan perburukan yang cepat; (4) Onset akut deteriorasi neurologis ringan dengan perburukan yang gradual dalam beberapa bulan. (1)

Sama halnya dengan space ocuppaying lession pada spinal cord lainnya, cavernoma memberikan efek kompresi pada spinal cord. Gejala yang paling sering muncul adanya defisit sensorimotor yang progresif dan sering disertai dengan adanya nyeri radikular atau nyeri sentral. Karena ukuran cavernoma seringkali kecil dan tumbuh secara lambat, cavernoma sangat jarang menyebabkan penurunan defisit neurologis fokal hingga titik terendah. Seringkali pasien mengeluhkan fluktuasi dari gejala tersebut. (6)

Cavernoma merupakan sebuah malformasi yang memiliki karateristik ukuran yang kecil, perdarahan yang asimptomatis dan memiliki batas yang tegas, dan hanya sesekali menyebabkan perdarahan yang hebat. (7) Insiden Perdarahan pada 
Intramedulary cavernoma sekitar 39\% dari kejadian intranedulary Cavernoma. Myelopati yang progresive bisa disebabkan oleh adanya microhemoragik dan perifokal gliosis sehingga dapat menyebabkan perburukan neurologis pada pasien. Beberapa angiogenik komponen seperti vascular endotelial, basic fibroblas growth factor, fibronectin dan tissue plasminogen activator dapat diekspresikan pada cavernoma. (8)

Terdapat beberapa modalitas lain yang dapat digunakan untuk mendeteksi atau mencurigai sebuah lesi ke arah cavernoma.CT-scan dapat membedakan antara kondisi low-grade tumor, hematoma, granuloma ataupun kondisi inflamasi lainnya. Pada tipe cavernoma yang terklasifikasi, pada gambaran CTScan dapat terlihat gambaran seperti meningioma. Pada CT-scan non kontras, cavernoma tampak sebagai lesi fokal yang berbentuk bulat atau lonjong, dengan pengingkatan ringan-sedang pada densitasnya. Kondisi hiperdens ini dipengaruhi oleh area yang terklasfikasi dan deposit hemosiderin pada dinding cavernoma dan darah yang terletak di dalam lesi. Pada CT-scan dengan kontras, akan terlihat gambaran yang lebih jelas, pada kondisi perdarahan, cavernoma hanya terlihat sebagai gambaran hemotama intraserebral pada CT-scan non-kontras, dengan penggunaan kontras, cavernoma yang ruptur tersebut dapat diidentifikasi sebagai sebuah nodul yang berbatas tegas dengan hematoma. (9)(10)

Pada MRI gambaran cavernoma yang terletak pada parenkim akan muncul dalam bentuk seperti popcorn, berbatas tegas, dimana pada intinya terlihat gambaran multiple fokus yang terdiri dari berbagai macam intensitas yang membentuk seperti sebuah network dan dikelilingi oleh sebuah lingkaran hipointens yang merepresentasikan hemosiderin dan yang menandakan terjadinya perdarahan dalam berbagai level dan evolusi cavernoma itu sendiri.(4)

Pada gambaran MRI Medula spinalis pada pasien ini didapatkan gambaran suatu masa yang heterogen dengan komponen hipo dan hyperintens yang berbentuk seperti Popcorn atau buah murrbery. Terdapat spesifikasi pada imaging pada masa tersebut yang berupa cincin hipodens yang mengelilingi area hiperdens yang merupakan suatu deposit hemosiderin. Pada spinal cord setinggi C2 hingga C4 didapatkan suatu gambaran hiperintens pada T1 dan T2 yang diduga suatu perdarahan sub kronis $(>7$ hari). (9)

Tabel 1. Grading Cavernoma berdasarkan MRI

\begin{tabular}{|c|c|c|}
\hline Type & MRI features & Pathology features \\
\hline I & $\begin{array}{l}\text { T1: hyperintense core } \\
\text { T2: hyper- or hypointense core }\end{array}$ & Subacute hemorrhage \\
\hline II & $\begin{array}{l}\text { T1: reticulated mixed signal core } \\
\text { T2: reticulated mixed signal core with } \\
\text { surrounding hypointense rim }\end{array}$ & Lesions with thrombosis of varying ages \\
\hline III & $\begin{array}{l}\text { T1: iso- or hypointense } \\
\text { T2: hypointense lesion with hypointense } \\
\text { rim magnifying size of lesion }\end{array}$ & $\begin{array}{l}\text { Chronic hemorrhage with hemosiderin staining } \\
\text { within and around lesion }\end{array}$ \\
\hline IV & $\begin{array}{l}\text { T1: not seen } \\
\text { T2: not seen } \\
\text { GRE: punctate hypointense lesion }\end{array}$ & Tiny cavernoma or teleangiectasia \\
\hline
\end{tabular}

Beberapa differensial diagnosa yang perlu dipikirkan berdasarkan pemeriksaan fisik dan imaging antara lain; arteriovenous, capillary and venous malformation, primary nervous tissue tumors seperti ependimoma dan astrocytoma. Pada kasus ependimoma akan tampak pada MRI sebagai masa berbentuk kistik dan jarang yang menyangat dengan pemberian kontras dan jarang terdapat flow void. Pada astrocytoma akan tampak sebagai massa yang multisegmental dan menyangat dengan pemberian kontras serta jarang disertai perdarahan. Pada arteri vena malformasi akan tampak pembesaran flow void dengan adanya vascular nidus. Untuk itu perlu dilakukan Angiorafi atau DSA untuk membedakannya dengan suatu AVM. (9)(10)
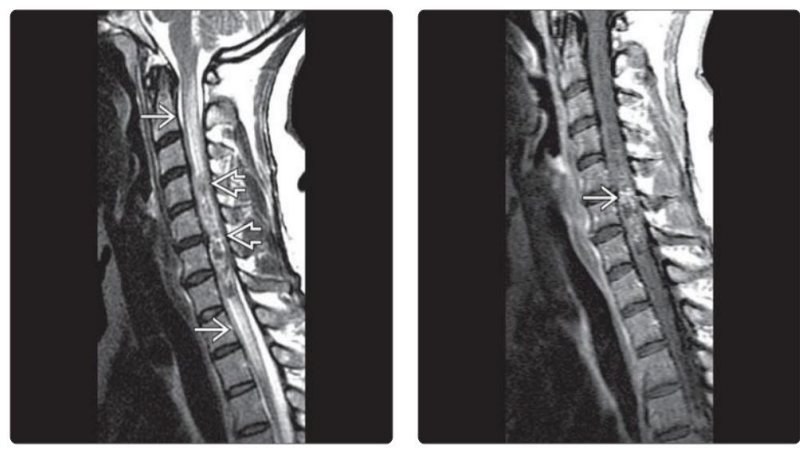

Gambar 3. MRI Sagital T2WI (Kiri) dan T1WI

(Kanan). Gambaran Perdarahan akut intramedular berasal dari ruptur cavernous hemangioma(9)

Cavernoma pada dasarnya merupakan lesi yang tidak terlalu berbahaya walaupun dapat menyebabkan kelumpuhan permanen. Beberapa hal yang perlu diperhatikan saat melakukan tindakan 
pembedahan adalah lokasi dari cavernoma itu sendiri, apakah dapat diakses atau tidak. (2)(11)

Pada kasus Cavernoma spinal cord simptomatik dianjurkan untuk dilakukan tidakan pembedahan. Pembedahan dilakukan dengan teknik microsurgery dengan total reseksi atau parsial reseksi. Perlu pertimbangan dalam memutuskan tindakan operatif pada pasien dengan cavernoma spinalcord, perlu dipertimbangkan umur pasien, resiko perdarahan post operatif dan lokasi massa yang akan dilakukan reseksi. Sama halnya dengan tindakan operatif didaerah yang kaya akan pembuluh darah, resiko untuk terjadi perdarahan intraoperatif dan post operatif sangat besar. Reseksi parsial mempunyai kemungkinan perdarahan postoperatif yang besar, untuk itu perlu pengawasan hemostatik yang ketat. (12)

Mikroreseksi dilakukan pada tumor yang aksesibel dan pada lokasi yang tidak terjangkau atau dengan resiko perdarahan yang besar dapat dilakukan dengan radioterapi menggunakan gama knife.(13) Belum ada data yang cukup untuk menunjang apakah modalitas radioterapi dapat digunakan sebagai sebuah terapi definitive, terutama pada cavernoma yang terletak sangat dalam dan tidak accessible untuk dilakukan tindak pembedahan.(14) Tujuan utama tindakan pembedahan pada pasien cavernoma spinalcord adalah total reseksi tanpa adanya morbiditas neurologis. Untuk itu selama proses pembedahan dan pasca pembedahan diperlukan beberapa modalitas seperti; MEP, SSEP dan free runing EMG. MEP berguna untuk monitoring integritas bagian anterior dan lateral spinalcord. SSEP berguna untuk monitoring bagian posterior spinal cord. Free runing EMG bermanfaat dalam menilai adanya iritasi nerve roots selama pembedahan. Idealnya pembedahan dilakukan dengan kombinasi dengan intraoperatif neurophysiological monitoring(IONM). (12)

Pada pasien Cavernoma yang asimptomatik, maka dapat dilakukan perawatan secara konservatif dan dilakukan observasi ketat setiap 1 tahun atau 2 tahun dengan pemeriksaan MRI. Karena lesi ini jinak dan perkembangannya lambat, apabila tidak muncul gejala atau terjadi pertambahan dalam ukuran, maka tidak diperlukan tindakan pembedahan, walaupun pada beberapa institusi kesehatan, dilakukan metode radiosurgical dengan gamma knife untuk mereseksi cavernoma. ${ }^{(15)}$

Cavernoma dapat memiliki prognosis yang baik ataupun buruk tergantung letak dan dan kerusakan yang telah terjadi terhadap susunan saraf pusat. Cavernoma Batang Otak memiliki tingkat morbiditas dan mortalitas yang lebih tinggi ketimbang cavernoma supratentorial ataupun cerebellar. Cavernoma pada dasarnya adalah malformasi vascular yang cenderung berkembang secara lambat, dan jarang menimbulkan gejala, pengontrolan gejala dapat dilakukan secara konservatif ataupun secara pembedahan yang mana mempunyai hasil yang lebih baik ketimbang secara konservatif. (15)Pada kasus ini diagnosis pasti berdasarkan patologi anatomi belum dapat ditegakkan sehingga diagnosis imaging masih dijadikan pedoman dalam menatalaksana pasien secara konservatif.

\section{SIMPULAN}

Intramedulary spinal cord cavernous hemangioma merupakan malformasi vaskular yang jarang terjadi.. Cavernous Haemangioma memilki struktur dinding yang rapuh dan sangat rentan terjadi ruptur. Pembedahan dilakukan dengan teknik microsurgery dengan total reseksi atau parsial reseksi. Cavernoma dapat memiliki prognosis yang baik ataupun buruk tergantung letak dan dan kerusakan yang telah terjadi terhadap susunan saraf pusat.

\section{SARAN}

Perlu pemeriksaan imaging lanjutan pada cavernous hemangioma. DSA memberikan gambaran yang sangat membantu dalam penatalaksanaan operatif pasien tersebut.

\section{DAFTAR PUSTAKA}

1. Kim DH, Chang Uk,Kim SH, Bilsky MH. Tumors Of the Spine. Philadhelpia: Elsevier;2008:95103

2. Kivelev J,Dashti R,Porras M,Tyyninen O,Hernesniemi J.Brain and Spinal Cavernoma / access and utilization (Dissertation).University of Helsinski.2010

3. Raqeeb $\mathrm{H}$, Kellner $\mathrm{CP}$, Solomon RA. "Cavernous Malformations of the Brainstem" Clinical Neurosurgery, 2008;Vol.55: 88-96.

4. Poeata I,lencean ST. "Cerebral Cavernoma." Romanian Neurosurgery, 2008; Vol XVI:14-17.

5. Kayali H,Sait S, Serdar K, Kaan O,llker S,Erdener T. "Intracranial Cavernoma: Analysis 
of 37 Cases and Literature Review." Neurology India, 2004;Vol.52(4):439-442.

6. Victor M, H Ropper AH. Adams and Victor's Principles of Neurology. 9e. United States: McGraw Hill, 2009:681-85

7. Raychaudhuri R,Batjer H,Awad IA. "Intracranial cavernous angioma: a practical review of clinical and biological aspects." Surgical Neurology, 2005; Vol.63: 319-328.

8. Kondziella D, Brodersen $\mathrm{P}$, Laursen $\mathrm{H}$, Hansen $\mathrm{K}$. Cavernous hemangioma of the spinal cord conservative or operative management?. Acta Neurol Scand 2006: 114: 287-290

9. Ross JS, Moore KR. Diagnostic imaging Spine. 3rd edition.Philadelphia Elsevier,2015:904-908

10. North PE. Histology of Vascular Malformations. In: Mattassi R, Loose DA, Vaghi M Editors. Hemangioma and Vascular Malformation. 2nd ed. London: Springer,2015:171-185

11. Rahyussalim A, Situmeang A, Safri AY, Zulfa IK.2015.Case repport : Intradural Intramedullary mixed type hemangioma; optimizing the surgical Management throught Intraoperative neurophysiological Monitoring. Case report in surgery Volume 2015;5. Artikel ID 984982 http://dx.doi.org/10.1155/2015/984982

12. Ameen M, Murthy S.2015.Dorsal Spinal Epidural Cavernous Haemangioma: A Case Report. IOSR Journal of Dental and Medical Sciences (IOSR-JDMS). Volume 14, Issue 8 Ver. I (Aug. 2015): 11-13

13. Pollock, Bruce E. "Radiosurgery for Cavernous Malformations: Theory and Practice." Clinical Neuorsurgery, 2008: 97-100.

14. Barrow DL,Schuette AJ. "Cavernous Malformations: A Paradigm for Progress." Clinical Neurosurgery, 2011; Vol 58:27-42.

15. Liang JT, Bao YH, Zang HQ, Huo LR, Wang ZY, Ling F. Management and Prognosis of symptomatic patient with intramedulary spinal Cord cavernoma.Jurnal of Neurosurgery.Spine. 2011 Oct ;Vol. 15(4);447-456. 